\title{
Recycle Florida Today and Florida Organics Recyclers Association: Then, Now, and Beyond
}

Joan Bradshaw ${ }^{1}$ and Monica Ozores-Hampton ${ }^{2}$

\begin{abstract}
Additional INDEX WORDs. recycling, compost, municipal solid waste, garbage, biosolids, sewage sludge, organic recycling, mulching, waste management, food waste, yard trimmings, yard trash, yard waste, wood waste, poultry manure, manure, land clearing debris
\end{abstract}

Summary. In 1988, the Florida Legislature passed the Solid Waste Management Act that affected the solid waste disposal practices of every county in the state. With legislation directly affecting the industry, organic recyclers and Florida Department of Environmental Protection (FDEP) regulators recognized a need to establish a professional organization that could serve as a unified industry voice, and foster high standards and ethics in the business of recycling and reuse of organic materials. In December 1994, a meeting was held to discuss the formulation of a Florida organic recycling association which became known as the Florida Organics Recyclers Association (FORA). FORA's first major contribution to the industry was the development of a recycling best management practice manual for yard trash in 1996. The second major project undertaken by FORA was a food waste diversion project which sought to promote an increase in food waste recovery and reuse. In Spring 1999, FORA became the organic division of Recycling Florida Today (RFT) further unifying recycling efforts within the State of Florida. In an attempt to address mounting concerns regarding industry marketing and promotional needs, RFT/FORA developed an organic recycling facility directory for the State of Florida in Spring 2000. Most recently RFT/FORA developed an organic recycling facility operator training course outline to assist the FDEP in identifying industry training needs. From its modest beginnings in 1994, to future joint programming efforts with the University of Florida's Florida Organic Recycling Center for Excellence (FORCE), RFT/FORA continues to emerge as a viable conduit of educational information for public and private agencies relative to organic recycling in Florida.

$\mathrm{F}$ Tlorida is characterized by a subtropical climate resulting in ideal conditions for 9-month horticultural growing seasons. Warm climatic conditions, heavy applications of water-soluble nitrogen fertilizer and scheduled irrigation practices contributed to the generation of 3.5 million tons $\left(3.2 \times 10^{6} \mathrm{t}\right)$ per year of residential and commercial yard trimmings (Esser and Gaskalla. 1994). Waste composition studies initiated in the late 1980s indicated that municipal solid waste amounted to $30 \%$ of the annual waste stream. Recognizing large volumes of organic materials were being generated in the State of Florida, measures were implemented by FDEP to encourage resource recovery and recycling (Goldstein, 1994; Stasis et al., 1992). In 1988, the Florida Legislature passed the solid waste management act (FDEP, 1988) which affected the solid waste disposal practices of every county in the state.

\footnotetext{
Florida Agricultural Experiment Station journal series R-08569

${ }^{1}$ City of St. Petersburg, 1635 Third Avenue North, St. Petersburg, FL 33713.

${ }^{2}$ University of Florida, Southwest Florida Research and Education Center, 2686 State Road 29 North, Immokalee, FL 34142-9515; to whom reprint request should be addressed.
} 
This law mandated that each county reduce the amount of solid waste generated by $30 \%$ by 1994 , challenging counties to seek methods of reducing the solid waste stream. Chapter 62-709 (FDEP, 1989), Florida administrative code, commonly known as the composting rule, was initiated in 1989. This legislation was designed to regulate the production and encourage the use of compost made from solid waste while protecting state lands and water resources.

On 10 Jan. 1995, the policy coordinating committee of FDEP approved the request to eliminate the permitting requirements for yard trimming waste composting facilities that were regulated by Chapter 62-709 (FDEP, 1988). This exemption applied exclusively to those facilities that compost yard trimmings waste and clean wood. FDEP continued monitoring and enforcing regulations on yard trimming waste facilities that operate in a manner that is potentially detrimental to the environment. With the deregulation of the yard trimming waste recycling industry, a need existed for assessing industry's ability to effectively self regulate through implementation of best management practices (BMP).

\section{The need for an organic recycling organization}

With legislation directly affecting the industry, organic recyclers and FDEP regulators recognized a need to establish a professional organization which could serve as a unified industry voice in response to organic recycling issues. It became clear that an organic recycling organization was needed to foster high standards and ethics in the business of recycling and reuse of organic materials. It was also widely recognized that a need existed to identify and implement appropriate recycling practices to operate in an environmentally sensitive manner.

\section{Historical perspective of FORA}

In December 1994, public and private industry representatives held a meeting in conjunction with the southeast BioCycle conference to discuss the need to establish FORA. This effort was the impetus for the December 1994 meeting of the group that would become known as FORA. Eleven committed organic recyclers served on the original board directors with three representatives of the public sector, five representatives of the private sector, one consultant and two University of Florida faculty. The FORA board established the following organizational goals.

- Foster high standards and ethics in the business of recycling and reuse of organic materials.

- Serve as a unified voice on issue related organic recycling issues.

- Assure safe production and beneficial use of compost, mulch and other organic materials.

- Inform and educate the public, governmental agencies, and business community on information relative to organic recycling.

- Assist in the development of markets for mulch, compost and other organic materials.

- Work in conjunction with state agencies to assist in the development, implementation and enforcement or rules and regulations related to organic recycling.

- Assist in identifying areas of research/development as it relates to the recycling and reuse of organic materials.

In 1995 , a study was initiated by a FORA board member to determine educational needs and characteristics of the organic recycling industry. The target population of the study consisted of Florida yard trimming waste recyclers to include composters, mulch producers, and fuel producers. A census was taken of the entire population of 90 yard trimming waste recycling facilities. To obtain the requisite information for the study, a closed form questionnaire was developed. Descriptive statistics were utilized to summarize characteristics of yard trimming waste recycling. The industry was characterized according to 1 ) recycling methodologies used, 2) management type, and 3 ) production concerns. Results of the study indicated that Florida yard trimming waste recyclers implement multiple recycling methods. According to the data, of the 90 yard trimming waste recyclers, $14 \%$ of the operations functioned exclusively as composters, $12 \%$ of the operations implemented both composting and mulching programs, $11 \%$ of the facilities implemented composting, mulching and fuel production programs, $43 \%$ of the industry exclusively functioned as mulching operations, $9 \%$ of the fa- cilities served as both mulching and fuel production operations, $4 \%$ of the industry exclusively processed yard trimmings waste for fuel production, and $5 \%$ of the respondents represented other aspects of the yard trimming waste industry such as consultants, educators and brokers.

Management of yard trimming waste recycling operations was described as publicly supervised by municipal or county governments or privately managed by commercial businesses. Of the 90 yard trimming waste recycling operations in Florida, $51 \%$ of the yard trimming waste recycling organizations were privately managed and $49 \%$ of the facilities were publicly managed.

Another goal of the study was to identify production concerns affecting the industry. Concerns which typically arise within the yard trimming waste recycling industry are feedstock contamination, maintaining target pile temperatures, creating a consistent end product, lack of adequate space for production, dust control, odor control, lack of efficient equipment and production costs. The results of the study are summarized as follows.

- $37 \%$ of the industry expressed concerns about a consistent end product.

- $31 \%$ of the respondents indicated concerns about production costs.

- $22 \%$ of the respondents expressed concerns about feedstock contamination.

- $20 \%$ of the recyclers were concerned with lack of adequate production space.

- $31 \%$ of the respondents indicated concerns about production costs.

- $19 \%$ of the yard trimming waste recyclers expressed concerns about odor control.

- $10 \%$ of the respondents indicated concerns about dust control.

- $7 \%$ of the respondents indicated concerns about maintaining target windrow temperatures.

\section{FORA educational efforts to meet growing industry needs}

In May 1996, FORA began addressing a variety of industry's needs via the development for Florida of best management manual practices for recycling yard trash. A joint effort was initiated between FORA, the Florida 
Center for Solid and Hazardous Waste Management, and FDEP. Eight industry representatives and FDEP staff formulated a design team to draft an outline of essential topics for inclusion in a best management practice manual for yard trash recycling. Following the development of the outline, three regional workshops were then held with industry representatives to ensure that appropriate topics had been incorporated into the outline. To provide consistency and continuity in writing styles, the design team met and began formulating the manual based on the industry-generated outline. Following three peer reviews, the eight-chapter document was finalized and forwarded to FDEP for publication and distribution. The final document, "Recycling Yard Trash: Best Management Practices Manual for Florida" (FORA, 1996a), included the following topics.

FLORIDA YARD TRASH COMPOSITION AND CHARACTERISTICS. Florida municipal solid waste composition, Florida yard trash composition by region, weight and volume characteristics.

YARD TRASH RECYCLING ALTERNAtIves. Composting, mulching, fuel application, landfill cover amendment, slope stabilization, wetland mitigation, and firewood

FUNDAMENTALS OF COMPOST PRODUCTION. Contamination, feedstock preparation, oxygen and aeration, participle size and surface area, moisture content, carbon to nitrogen ratio, temperatures, $\mathrm{pH}$, pathogens, compost stability.

Fundamentals Of MULCh PRODUCTION. Types of mulch, characteristics, fresh mulch, sanitized mulch, log mulch

FUNDAMENTALS OF FUEL PRODUCTION. Material description, particle size, product storage, non-wood contamination, moisture content, ash content, British-thermal-units value.

FACILITY SITING AND DESIGN. Site location, permitting requirements, local zoning and building requirements, local environment agencies, water management districts, FDEP setback, buffers, entrance and exit requirements, storm water control, peculation slope, retention or detection, land area requirements, projections for site capacity and layout for composting and mulching facilities, staging area, processing area storage and curing area, internal circulation site surface and sub surfacing, utilities, security, signage, and material measurement.

Operational considerations. On-site personnel, incoming materials consideration, separation by materials types, plastic and paper bags, grass, contaminants, storage parameters, size reduction, processing times, pile to alley relationships, dust control, bio aerosols, odors, noise, pest and insect control, fire prevents, fire fighting, employee safety and health, materials turning and screening.

Product considerations. Compost products, mulch products, fuel products, record keeping, product testing, representations of products and marketing guidelines.

More than 2,000 hard copies of the publication were distributed around the state. The manual is available from the FDEP or online (FORA, 1996b).

\section{Food waste diversion in Florida}

In November 1998, the University of Florida Center for Biomass Programs and the FORA board recognized that food waste constituted a significant portion of the Florida waste stream and this resource had not been widely targeted as a recoverable material. This being the case, work began on the food waste diversion project representing an initial step toward promoting an increase in food waste recovery and reuse. This educational and market development program was designed as follows.

- Identify major food waste generators in Florida to provide a statewide perspective on food waste generation and recovery.

- Develop and distribute educational material that described available options for collecting, processing and marketing recovered food waste.

- The culmination of these efforts gave rise to a 1 -d food waste recycling workshop designed to inform major generators of food waste of Florida.

\section{FORA unites with RFT}

Recycle Florida Today is an association dedicated to promoting successful recycling in the State of Florida. Begun in 1990, RFT's mission is to improve skills and techniques of the recycling industry as well as serve a forum for public, private and non- profit recycling to mutually discuss and resolve recycling issues. Driven by the similarity of missions, FORA became the organic division of RFT in Spring 1999, further unifying recycling efforts within the state of Florida. No longer having to manage administrative details, FORA was now able to focus extensively on organizational goals of education and outreach efforts.

\section{Organic recycling facility directory}

In Spring 2000, efforts were made by RFT/FORA to address marketing and promotional needs of the industry via the development of an organic recycling facility directory for the state of Florida (RFT, 2000). The purpose of this publication is as follows.

- Assist in the marketing of recycled organic products.

- Provide a single source product information guide for potential users of organic products.

- Provide a source of producer information for regulators, product and equipment vendors.

A survey was developed and forwarded to more than 500 potential organic recycling information sources. Followup letters were sent to nonrespondents, and telephone calls were made to more than 200 individuals, resulting in compilation of information on 75 organic recycling facilities. The resulting directory included organic recycling facilities receiving one or more of the following feedstocks for processing into organic products: yard trimmings waste, manures, food waste, land clearing debris, clean wood waste, municipal solid waste and biosolids. Other pertinent information included in the directory are number of years in business, annual tonnage, annual volume. Feedstocks used in the processing were reported according to poultry manure, biosolids, cow manure, fish waste, yard trimming waste, food waste, wood waste, land clearing debris, municipal solid waste and others. End product use was also reported in the directory according to mulch, fuel, soil mixes, compost and others. Facilities also provided information on other services they provide grinding, mulch coloring, marketing, screening, trucking and/or installation.

This grant-funded project was supported by FDEP and upon completion the directory will be available in 
printed form and on the FDEP's and RFT's web sites. The resulting Florida organic recycling facility directory will include an alphabetical listing of facilities by county and facility contact listing. Data collected during the development of the directory will serve as an information source for revision and modifications to the industry profile created during the early FORA years.

\section{Organic recycling facility operators training course outline}

Most recently, a cooperativefunded effort was established between the FDEP and RFT/FORA to develop an organic recycling facility operator training course outline. The impetus for creating a training course resulted from FDEP's desire to provide best management practice training for permitted facilities throughout the state of Florida. A committee was formulated and a literature review was implemented to determine training programs being offered throughout the U.S. The FORA committee chair attended the U.S. composting council's meeting on compost operators training courses in Chicago. Twelve state representatives were present to discuss training programs being offered and those in the planning stages. Following the literature review process, 15 Florida private and public sector representatives, University of Florida faculty and FDEP staff met to identify relevant topics for inclusion in a Florida organic recycling facility operator training course. The committee developed a 2 - $d$ course outline and recommended the length of the course could be extended to 3 to $4 \mathrm{~d}$ to include hands-on training and site tours to address the specifics of composting and other specialty materials.

In Oct. 2000, the public and private sectors were invited to a halfday workshop soliciting comments and recommendations on the proposed organic recycling facility operator training. The outline is as follows.

- Introduction of the training course.

- Composting biology and core principles.

- Feedstock(s) types, preparation, collection, recovery.
- Facility siting, design/layout, operations, record keeping, maintenance.

- Compost process, management, equipment and technologies.

- Marketing promotion and uses.

- Product quality, screening, refining, curing (stability/maturity).

- Benefits of organic utilization.

- Regulations, regulatory compliance and permitting.

- Health and safety requirements.

- Product, process, personnel, facility economics and business trouble shooting.

- Odor and dust management.

- Fire control.

The final outline of the organic recycling facility operator training course was submitted to FDEP in November 2000. Budget constraints have prevented further action on this program.

\section{RFT/FORA and beyond}

Over the past decade, the passing of solid waste management legislation has not only affected the organic recycling industry, but RFT/FORA has been equally impacted. Legislative actions have stimulated RFT/FORA's efforts in working with yard trimming waste recyclers. RFT/FORA has successfully served as a unified voice relative to organic recycling issues as well as fostered high standards and ethics within the industry. While accomplishments have been made in the area of yard trimming waste recycling, much work needs to continue relative to the recycling of manures, municipal solid waste, biosolids, fish waste, food waste and land clearing debris.

With the recent collaborative efforts of the University of Florida and FDEP proposing to develop the FORCE, the future for industry and RFT/FORA is very bright. From its modest beginnings in 1994, to future joint programming efforts with FORCE, RFT/FORA continues to emerge as a viable conduit of educational information for public and private agencies relative to organic recycling in Florida. RFT/ FORA's future lies in the continued realization of the vision of safe production and beneficial use of compost, mulch, and other organic materials within the State of Florida.

\section{Literature cited}

Esser, R. and R. Gaskalla. 1994. National composting survey results 1993-1994. Fla. Div. Plant Ind., Tallahassee.

Florida Organic Recyclers Association. 1996a. Recycling yard trash: Best management practices manual for Florida. Fla. Dept. Environ. Protection, Tallahassee.

Florida Organic Recyclers Association. 1996b. Recycling yard trash: Best management practices manual for Florida. 2 Jan. 2002. <http://www.dep.state.fl.us/ waste/quick_topics/publications/documents/yard_trash.pdf>.

Florida Department of Environmental Protection. 1988. Solid Waste Management Act. Florida Statutes, Title XXIX, Public Health Chapter 403, Environmental Control, Chapter 403.705. Fla. Solid Waste Mgt. Prog., Tallahassee.

Florida Department of Environmental Protection. 1989. Criteria for the production and use of compost made from solid waste. Chapter 62-709, Fla. Admin. Code.

Goldstein, N. 1994. Guidelines and permitting for yard trimming composting. BioCycle 12:62-65.

Recycle Florida Today. 2000. Organic recycling facilities in Florida. Florida Organic Recyclers Assn., Recycle Florida Today, Dept. Environ. Protection, Tallahassee.

Stasis, P., R. Ragsdale, M. Rudd, and J. Bradshaw. 1992. Yard waste composition and effects on compost and mulch production. U.S. Environmental Protection Agency. Proc. 2 ${ }^{\text {nd }}$ U.S. Conf. Municipal Solid Waste Mgt., Arl., Va., 2-5 June. 